\title{
Secondary School Teachers' Journey from Self-Efficacy to Collective Efficacy
}

\author{
${ }^{\text {a }}$ Najam ul Kashif, ${ }^{\mathrm{b}}$ Musarrat Jahan, ${ }^{\mathrm{c}}$ Muhammad Latif Javed, ${ }^{\mathrm{d}}$ Rabia Bahoo \\ ${ }^{a}$ Assistant Professor, Department of Education, The Islamia University of Bahawalpur, Pakistan \\ Email: drnajam.ulkashif@iub.edu.pk \\ ${ }^{\mathrm{b}}$ Assistant Professor, Department of Special Education, The Islamia University of Bahawalpur, Pakistan \\ Email: musarrat.jahan@iub.edu.pk \\ ${ }^{c}$ Assistant Professor, Department of Education, The Islamia University of Bahawalpur, Bahawalnagar Campus, \\ Pakistan \\ Email: latif.javed@iub.edu.pk \\ ${ }^{\mathrm{d}}$ Assistant Professor, Department of Education, Government Sadiq College Women University, Bahawalpur, \\ Pakistan \\ Email: rabia.bahoo@gscwu.edu.pk
}

\begin{tabular}{l}
\hline ARTICLE DETAILS \\
\hline History: \\
Accepted 30 July 2021 \\
Available Online September 2021
\end{tabular}

\section{Keywords:}

Self-Efficacy, Collective-Efficacy,

Teachers, Secondary School Level

\section{JEL Classification:}

$P_{36}$

DOI: $10.47067 /$ real.v4i3.181

\section{ABSTRACT}

Education is perceived as a powerful agency, which instrument in bringing about the desired changes in the social, economic and cultural life of any nation. The whole process of education is shaped and molded by the human personality called the teacher. Teaching is a challenging profession and only those teachers can shoulder the heavy responsibilities of nation building, who are adequately prepared and have sound professional attitude. Self-efficacy is belief of teachers about their own potential, skills, pedagogy, developing learning school environment while living within the limited resources. And when it turns to expectations of other stakeholders like principal, students, society as a collective capability of a group of teachers to influence student achievement is refers as collective teachers-efficacy. This study aimed at to highlight the relation and changing paradigms from teachers' self-efficacy to collective-efficacy. To achieve the set aim, survey research technique was adopted. Southern Punjab was the population of the study and target was selected by adopting multistage random sampling technique. Equal opportunity was given to both genders. Total sample of the study was 480 (principals were 30 , teachers 150, and students 300). Three different research tool were developed out of which first research tool was for knowing the teachers' self-efficacy as Teachers' Sense of Efficacy Scale (TSES) which was developed by Tschannen-Moran and Woolfolk Hoy in 2001. Second research tool was of knowing the Collective Efficacy Scale (CE-Scale) developed by Goddard and Woolfolk Hoy (2004). Third research tool was Omnibus T-Scale (OTS) developed by Hoy in 2002. The analysis of the collected data was done by using Statistical Package for Social Sciences (SPSS) software version 21. Findings of the study shows that secondary school teachers are fully confident regarding their skills, competencies, pedagogy and ready to face the challenges. At the same time, their principals have shown strong trust on their teachers, but students' opinion was different from the principals.

(C) 2021 The authors. Published by SPCRD Global Publishing. This is an open access article under the Creative Commons AttributionNonCommercial 4.0

Corresponding author's email address: latif.javed@iub.edu.pk 


\section{Introduction}

Teacher remains a central figure in all kind of classes and educational institutes. He has to perform different kind of duties like to attend the meetings with parents; to impart the policies and patterns of school management; to encounter the curriculum changes; to do students' assessment (formative and summative) and to handle the disruptive behavior of the students as well as have to face different challenges like instructional setting up; ensure students' learning with quality; fulfill the demands of society for the students; meet the practical life expectations of the students; bridging the institution with the economic needs of the society; and to polish the students' behavior positively. Teacher's workload has continued to an increase in both complexity and accountability. Such kind of mentioned expectations from teachers' show that teachers' self-belief is how much important to meet all these challenges.

Self-belief is self-efficacy, according to human motivation theorists. Albert Bandura's (1986), social cognitive theory in the context of self-efficacy, in which he has given the concept of self-efficacy as people's judgments of their own capabilities to create designated levels of performance. He said the self-efficacy is totally different from self-esteem and self-concept because self-efficacy is task specific (Goddard, Hoy, \& Hoy, 200o) and self-efficacy based on what people believe they are capable of doing in particular situation in the future about their own self (Hoy, 2004). Blackburn \& Robinson in 2008 describe self-efficacy as belief of teachers about their own potential to systematize and carry out the courses of actions that required accomplishing the teaching task successfully.

On the end, collective efficacy discussed as a group's common characteristic in its conjoint capabilities to put in order and carry out the courses of action required to produce given levels of attainments. It's not just the sum of individual members' efficacy beliefs, but also the product of the interactive dynamics of the group members (Goddard, Hoy, \& Hoy, 2000). It expresses perceptions of peoples, that they exchange to concern as the appearance potential of a social system as an entire. Collective efficacy beliefs are associated with teachers' job satisfaction (Caprara et al., 2003), workload stress (Jex \& Bliese, 1999), team's labor effectiveness (Little \& Madigan, 1997) as well as responsible for the effectiveness of a group or institution with students' achievement (Gibson, 2001; Goddard, Hoy \& Hoy, 2000).

Collective efficacy is parallel to self-efficacy as related with the responsibilities. That's why; it can suppose that there is a cause of collective teachers' efficacy, which will flourish if it is developed once. It also means like that to examine the personal and collective attitude coexistence permeating in one's everyday life. And school systems in which it is possible are high-quality examples of environments. Because the school principals or teachers have personal actions when everybody must perform their own farm duties, acquired actions are collective actions which people have to get in arrange form to attain many goals, that's why here are some trial in use to the school circumstance as interdependence (Klassen, Usher \& Bong, 2010). Previously described, these both viewpoints are selfgoverning, but the association among them shown by studies because they both depending on one another. The most successful instructional actions are related the awareness of teacher self-efficacy, as well as humanistic approach based on classroom organization, consist on these aspects which support learning, inspiration, self-sufficiency, and student presentation (Gibson, 2001).

Teachers' self-efficacy has a great importance on students' achievements and success. And it can produce a great amount of stressful situations for the classroom teacher. But there is another point that is collective efficacy of school teachers. It includes overall performance of school managements and 
teachers that is necessary for students learning. Classroom management, instructional practices, and student engagement are taken as the common components of teachers' self and collective efficacy. So, the study was aimed to highlight the inclination of teachers' self-efficacy to collective efficacy.

\section{Research Methodology}

This study investigated the nature of teachers' self-efficacy and teachers' collective efficacy and its relationship in the schools to determine whether a common set of beliefs and values were evidenced by instructional practice and programming among the participating schools. Researcher used the Mixed Method Approach. All secondary school teachers and students of three (03) divisions of southern Punjab i.e. Bahawalpur, Multan and Dera Ghazi Khan was the population of the study. One district was selected from each division and one tehsil was selected from each district by adopting simple random sampling technique. From each tehsil, 10 secondary schools were randomly selected and gave equal portion to gender. From each selected school, its principal with his/her five (05) teachers and ten (10) students were the target sample of the study.

Three questionnaires were used as instruments to collect data. These survey instruments were included items design to collect data about teacher demographics, teacher assumptions and beliefs about teacher self-efficacy and collective efficacy of secondary school teachers. To measure Teachers' Sense of Self-Efficacy questionnaire was contain on some items related to these factors; (a) teachers' competencies and (b) teachers' pedagogy and (c) school environment created by teachers and school facilities. Another questionnaire was designed to get information about teachers' collective efficacy by principal and factors are; (a) teachers' relationship with students, (b) teachers' relationship with principals and (c) students' relationship with principals. And third questionnaire was developed to get information about teachers' collective efficacy by students with the factors; (a) teachers' challenges, and (b) teacher's skills. Participants were completed each item by rating it using a five-point Likert-Like scale. Statistical Package for Social Science (SPSS) version 21, software was used to analyze the collected data.

\section{Results}

\subsection{Collective Efficacy of Teachers by students}

\section{Factor 1: Teachers' competence}

The first factor of teachers' self-efficacy scale was based on teachers' competence and it contained nine (og) items. And accumulate mean of this factor was 3.96.

\section{Factor 2: Teachers' Pedagogy}

The second factor of teachers' self-efficacy scale was based on teachers' pedagogy and it contained six (6) items. And accumulate mean of this factor was 2.79.

\section{Factor 3: Schools' Environment created by teachers and school facilities}

The third factor of teachers' self-efficacy scale was based on schools' environment created by teachers with the coordination of principals and students and school facilities. The scale contained three (3) items. And accumulate mean of this factor was 3.48 
Table 4.1: Comparison of gender differences on collective efficacy of teachers

\begin{tabular}{|c|c|c|c|c|c|c|c|c|}
\hline S. \# & Factor & Location & $\mathrm{N}$ & Mean & $\mathrm{t}$ & $\begin{array}{l}\text { Sig. } \\
(2- \\
\text { taile } \\
\text { d) }\end{array}$ & M.D & Sig. \\
\hline \multirow[t]{2}{*}{1} & \multirow[t]{2}{*}{ Teachers competence } & Male & 150 & 3.9807 & .674 & \multirow[t]{2}{*}{.501} & \multirow[t]{2}{*}{.025} & \multirow[t]{2}{*}{.212} \\
\hline & & Female & 150 & 3.9385 & .674 & & & \\
\hline \multirow[t]{2}{*}{2} & \multirow[t]{2}{*}{ Teachers' Pedagogy } & Male & 150 & 2.7656 & -.521 & \multirow[t]{2}{*}{.603} & \multirow[t]{2}{*}{.030} & \multirow[t]{2}{*}{.361} \\
\hline & & Female & 150 & 2.8133 & -.521 & & & \\
\hline \multirow[t]{2}{*}{3} & \multirow{2}{*}{$\begin{array}{l}\text { School Environment } \\
\text { And School Facilities }\end{array}$} & Male & 150 & 3.5467 & 1.768 & \multirow[t]{2}{*}{.078} & \multirow[t]{2}{*}{-.009} & \multirow{2}{*}{.003} \\
\hline & & Female & 150 & 3.4133 & 1.768 & & & \\
\hline
\end{tabular}

Table 4.1 demonstrates the impact of gender on teachers' collective efficacy. This scale measures the collective efficacy of teachers with three (3) factors. This table shows the result that, the gender has no impact on teachers' competence and teaching methods. All the teachers who are male or female have shown the equal efficacy. There is significance difference in school environment between male and female teachers' opinion (Male: 3.546, Female: 3.413).

\subsection{Collective Efficacy of Teachers by Principal}

Factor 1: Relationship between Teachers and Student

The first factor of collective efficacy of teachers by Principals' scale was based on teachers' relationship with their students and this factor contained seven (7) items. And accumulate mean of this factor was 3.81

\section{Factor.2: Relationship between Principal and Teacher}

The second factor of collective efficacy of teachers by Principals' scale was based on teachers' relationship with their principals and this factor contained eight (8) items. And accumulate mean of this factor was 3.58

\section{Factor 3: Relationship between Principal and Student}

The third factor of collective efficacy of teachers by Principals' scale was based on principals' relationship with their students and this factor contained five (5) items. And accumulate mean of this factor was 3.89

Table 4.2: Comparison of gender differences on collective efficacy of teachers

\begin{tabular}{|c|c|c|c|c|c|c|c|c|}
\hline S. \# & Factor & Location & $\mathrm{N}$ & Mean & $\mathrm{T}$ & $\begin{array}{l}\text { Sig. (2- } \\
\text { tailed) }\end{array}$ & M.D & Sig. \\
\hline \multirow[t]{2}{*}{1} & \multirow{2}{*}{$\begin{array}{l}\text { Teacher Student } \\
\text { Relationship }\end{array}$} & Male & 15 & 3.7524 & \multirow{2}{*}{.777} & \multirow[t]{2}{*}{.444} & .122 & \multirow[t]{2}{*}{.244} \\
\hline & & Female & 15 & 3.8746 & & & & \\
\hline \multirow[t]{2}{*}{2.} & \multirow{2}{*}{$\begin{array}{l}\text { Principal } \\
\text { Teacher } \\
\text { Relationship }\end{array}$} & Male & 15 & 3.5750 & \multirow[b]{2}{*}{-.043} & \multirow[t]{2}{*}{.966} & .008 & \multirow[t]{2}{*}{.550} \\
\hline & & Female & 15 & 3.5833 & & & & \\
\hline \multirow[t]{2}{*}{3} & \multirow{2}{*}{$\begin{array}{l}\text { Principal } \\
\text { Student } \\
\text { Relationship }\end{array}$} & Male & 15 & 3.8667 & \multirow[b]{2}{*}{-.349} & \multirow[t]{2}{*}{.730} & -.040 & .269 \\
\hline & & Female & 15 & 3.9067 & & & & \\
\hline
\end{tabular}


Table 4.2 demonstrates the impact of gender on teachers' collective efficacy. This scale measures the collective efficacy of teachers with three (3) factors. There is no impact of gender teachers' collective efficacy. This table shows the result that, each teacher who is male or female, they show the identical efficacy. There is no significance difference in teachers, students and principals' relationship between males and females' opinion.

\subsection{Teachers' Self Efficacy by Students}

Factor 1: Teachers' Challenges

The first factor of teachers' self-efficacy by Students' scale was based on teachers' challenges as they faced in their teaching and this factor contained seven (7) items. And accumulate mean of this factor was 3.91

\section{Factor 2: Teachers' Skills}

The first factor of teachers' self-efficacy by Students' scale was based on teachers' skills as they utilized them in their teaching and this factor contained seven (7) items. And accumulate mean of this factor was 3.86

Table.4.3: Comparison of gender differences on self-efficacy of teachers

\begin{tabular}{|c|c|c|c|c|c|c|c|c|}
\hline S. \# & Factor & Location & $\mathrm{N}$ & Mean & $\mathrm{t}$ & $\begin{array}{l}\text { Sig(2- } \\
\text { tailed })\end{array}$ & M.D & Sig. \\
\hline \multirow[t]{2}{*}{1} & \multirow{2}{*}{$\begin{array}{l}\text { Teachers } \\
\text { Challenges }\end{array}$} & Male & 75 & 4.0024 & \multirow{2}{*}{2.097} & .038 & \multirow[t]{2}{*}{0.18303} & \multirow[t]{2}{*}{.384} \\
\hline & & Female & 75 & 3.8194 & & & & \\
\hline \multirow[t]{2}{*}{2} & \multirow{2}{*}{$\begin{array}{l}\text { Teachers } \\
\text { Skills }\end{array}$} & Male & 75 & 3.9107 & \multirow{2}{*}{1.078} & .283 & \multirow[t]{2}{*}{0.10043} & \multirow{2}{*}{.947} \\
\hline & & Female & 75 & 3.8103 & & & & \\
\hline
\end{tabular}

Table 4.3 demonstrates the impact of gender on teacher's self-efficacy. This scale measures the self-efficacy of teachers with two (2) items. Results of this table shows that gender don't have any impact on teachers' challenges and teachers' skills. All the teachers who are male or female have shown the equal efficacy. There are no significant differences in male or female teachers' opinion.

\section{Discussion}

Education is perceived as a powerful agency, which instrument in bringing about the desired changes in the social cultural life of any nation. The whole process of education is shaped and molded by the human personality called the teacher, who plays a vital role in any system of education. This is challenging profession and only those teachers can shoulder the heavy responsibilities of nation buildings, who is adequately prepared and have sound professional attitude. That's why for a teacher to fulfill their duties and to teach the students effectively the teachers' self-efficacy is very important factor. Self-efficacy is belief of teachers about their own potential to systematize and to carry out the courses of actions that required accomplishing the teaching task successfully (Blackburn \& Robinson, 2008). The teachers' belief about the collective capability of a group of teachers to influence student achievement is refers as collective teacher efficacy.

The results of this study were based on analysis and interpretation of the collected data by using of Research tools (Questionnaires) each for all the stakeholders of the study i.e. teachers, their head and their students. According the respondents' views the secondary schools' teachers of southern Punjab are full of confident regarding their pedagogy and school environment which they 
have established with coordination of principals and students as called collective efficacy. According to respondents, the secondary school teachers of Southern Punjab can do great deal to motivate their students, to handle noisy or disruptive student and can teach their students effectively because they are self-efficacious. That's why the overall perception is the secondary school teachers of southern Punjab are full of confident they face any challenging situation on daily basis at school or classroom. The school principals have a strong relation and communication with their students so, their students can trust on them to share anything about teachers and school matters. And it reflects their strong collective efficacy. The above discussion and results can be summarized in the following diagram.

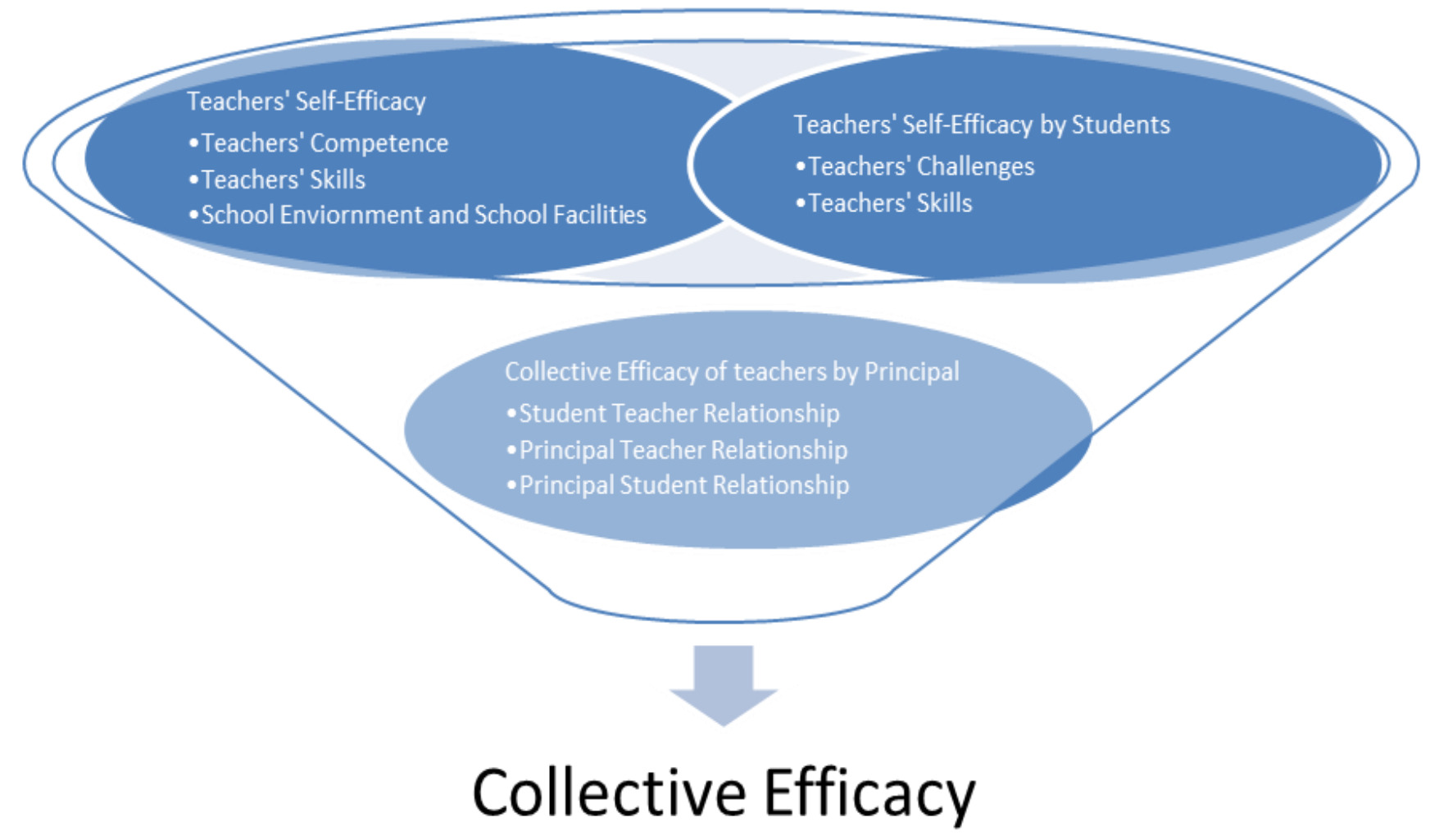

Figure: 1

\section{Conclusion}

The study concluded with the following lines that secondary school teachers are full of confidence on their competencies and pedagogy. They can handle any situation or most difficult students in their best possible way and their principals are also appreciating the competencies of teachers and pedagogy but at the same time students are slightly not satisfied with the competencies of their teachers, especially regarding their pedagogy. According to them, their teachers sometimes fail to justify their answers or teaching patterns. For them, teacher must try to teach with different teaching techniques if a child doesn't learn by one method. At the same time, there is visible positive learning environment of schools which is the proof of teachers' collective efficacy. In very limited resources, schools are meeting the national standards of school environment. Student-Teacher relationship and their communication is strong in majority of schools as well as there are majority of students who believe that their teachers are giving them their potentials. It very unfortunate that principal-student relation and communication is not as strong as student-teacher relation was. 


\section{Recommendations}

In above mentioned discussion and conclusions of the study, following recommendations were made:

- Result show, if the teachers are confident on their competencies, skills, teaching methodology, and teaching strategies they can satisfies their students through their answer justification.

- Besides of these results show, if the teachers have a strong relation and communication with other staff members, principal and students they are at the high level of self-efficacy and collective efficacy.

- It is concluded that teachers must have intrinsically high self-efficacies. They tried to face challenging situation and they will not give up this at any situation.

- So, it is recommended that Government may focus on conduction of pre-service training and inservices training programs in their institution.

\section{References}

Blackburn, J.J., \& Robinson, J.S. (2008). Assessing teacher self-efficacy and job satisfaction of early career agriculture teachers in Kentucky. Journal of Agricultural Education, 49(3), 1-11

Caprara, G. V., Barbaranelli, C., Borgogni, L., \& Steca, P. (2003). Efficacy beliefs as determinants of teachers' job satisfaction. Journal of Educational Psychology, 95(4), 821-832.

Gibson, C. (2001). Me and us: Differential relationships among goal-setting training efficacy and effectiveness at the individual and team level. Journal of Organizational Behavior. 22, 789-808.

Goddard, R. D., Hoy, W. K., \& Hoy, a. W. (2000). Collective Teacher Efficacy: Its Meaning, Measure, and Impact on Student Achievement. American Educational Research Journal, 37(2), 479-507.

Hoy, A.W. (2004). What pre-service teachers should know about recent theory and research in motivation? Paper presented at the annual meeting of the American Educational Research Association, 28(2), 117-148.

Jex, S. M., \& Bliese, P. D. (1999). Efficacy beliefs as a moderator of the impact of work-related stressors: A multilevel study. Journal of Applied Psychology, 84(3), 349361

Klassen, R. M., Usher, E. L., \& Bong, M. (2010). Teachers' collective efficacy, job Satisfaction, job stress in cross-cultural context. The Journal of Experimental Education, 78, 464-486

Little, B. L., \& Madigan, R M. (1997). The relationship between collective efficacy and performance in manufactning work teams. Small Group Research, 28(4), 517534 